Article

\title{
Benzamide-4-Sulfonamides Are Effective Human Carbonic Anhydrase I, II, VII, and IX Inhibitors
}

\author{
Morteza Abdoli ${ }^{1,2}$, Murat Bozdag 1,* (D), Andrea Angeli ${ }^{1}$ and Claudiu T. Supuran 1,* (iD \\ 1 Dipartimento Neurofarba, Sezione di Scienze Farmaceutiche e Nutraceutiche, Università degli Studi di \\ Firenze, Via U. Schiff 6, Sesto Fiorentino, 50019 Florence, Italy; mortezaabdoli1987@gmail.com (M.A.); \\ andrea.angeli@unifi.it (A.A.) \\ 2 Department of Chemistry, Faculty of Science, Lorestan University, Khorramabad 6813833946, Iran \\ * Correspondences: bozdag.murat@unifi.it (M.B.); claudiu.supuran@unifi.it (C.T.S.); \\ Tel.: +39-055-457-3666 (M.B.); +39-055-457-3729 (C.T.S.)
}

Received: 11 May 2018; Accepted: 30 May 2018; Published: 1 June 2018

\begin{abstract}
A series of benzamides incorporating 4-sulfamoyl moieties were obtained by reacting 4-sulfamoyl benzoic acid with primary and secondary amines and amino acids. These sulfonamides were investigated as inhibitors of the metalloenzyme carbonic anhydrase (CA, EC 4.2.1.1). The human (h) isoforms hCA II, VII, and IX were inhibited in the low nanomolar or subnanomolar ranges, whereas hCA I was slightly less sensitive to inhibition $\left(\mathrm{K}_{\mathrm{I}} \mathrm{s}\right.$ of $\left.5.3-334 \mathrm{nM}\right)$. The $\beta$ - and $\gamma$-class CAs from pathogenic bacteria and fungi, such as Vibrio cholerae and Malassezia globosa, were inhibited in the micromolar range by the sulfonamides reported in the paper. The benzamide-4-sulfonamides are a promising class of highly effective CA inhibitors.
\end{abstract}

Keywords: carbonic anhydrase; human isoform; sulfonamide; benzamide; pathogens

\section{Introduction}

Benzamides incorporating 3- or 4-sulfamoyl moieties, such as derivatives A and B (Figure 1) were investigated [1,2] as inhibitors of the zinc metallo-enzyme carbonic anhydrase (CA, EC 4.2.1.1) [3-12] in this study, in the search of agents with intraocular pressure lowering effects [1,2]. The incorporation of a wide range of amino acid (AA) or dipeptide AA moieties in molecules $\mathbf{A}$ and $\mathbf{B}$ led to enhanced water solubility for topical administration within the eye. These compounds showed remarkable in vitro inhibitory effects, assayed by an esterase method with 4-nitrophenyl acetate as substrate, against isoforms hCA II and IV, involved in aqueous humor production within the eye [1-12].<smiles>N#CNC(=O)c1ccc(S(N)(=O)=O)cc1</smiles>

(A)<smiles>C=NNC(=O)c1ccc(Cl)c(S(N)(=O)=O)c1</smiles>

(B)

Figure 1. (A,B) Sulfonamides incorporating benzamide moieties, amino acid (AA) and dipeptide AA moieties [1,2]. 
The CA inhibitors (CAIs) belonging to the sulfonamide and sulfamate types have been used clinically for several decades as diuretics [13,14], antiglaucoma agents [15], and anti-obesity drugs $[16,17]$. More recently, a large number of studies showed that CA inhibition has profound antitumor effects by inhibiting hypoxia-inducible isoforms hCA IX and XII, overexpressed in many hypoxic tumors [18-22]. Furthermore, several proof-of-concept studies demonstrated the involvement of some CA isoforms in neuropathic pain $[23,24]$ and arthritis $[25,26]$, with the CAIs of sulfonamide and coumarin [27-30] types demonstrating significant in vivo effects in animal models of these diseases. Thus, the field of drug design, synthesis, and in vivo investigations of various types of CAIs is highly dynamic, with the action of a large number of interesting new chemotypes on these widespread enzymes being constantly studied [27-39]. As they catalyze the interconversion between carbon dioxide $\left(\mathrm{CO}_{2}\right)$ and bicarbonate with the formation of a proton, $\mathrm{CAs}$ are widespread in organisms all over the phylogenetic tree as seven distinct genetic families: the $\alpha_{-}^{-}, \beta_{-}^{-}, \gamma_{-}^{-}, \delta_{-}^{-}$, $\eta-, \xi-$, and $\theta$-CAs [3-12,40-47]. CAs participate in crucial physiologic processes connected to $\mathrm{pH}$ homeostasis, metabolism, transport of gases and ions, and secretion of electrolytes in virtually all living beings [3-12,40-47].

Apart from the inhibition of human (h) or other vertebrate CA isoforms, the interest in inhibiting such enzymes present in various pathogenic organisms (bacteria, fungi, protozoa, or worms) has presented the possibility of designing anti-infective agents with a novel mechanism of action [40-51]. Thus, in this paper, we explored novel CAIs belonging to the sulfonamide class, incorporating benzamide moieties similar to compounds reported earlier, but that were investigated for the inhibition of isoforms involved in important diseases, such as glaucoma (hCA II), neuropathic pain (hCA VII), or tumors (hCA IX), and ubiquitous off target isoform hCA I. Furthermore, we investigated whether this chemotype shows inhibitory effects against $\beta$ - and $\gamma$-class CAs from pathogenic bacteria (Vibrio cholerae) or fungi (Malassezia globosa).

\section{Results}

\subsection{Chemistry}

The classical coupling of carboxylic acid 1 with amines, in the presence of carbodiimides (EDCI) and hydroxybenzotriazole has been used for synthesis, as reported previously [1,2] (Scheme 1).

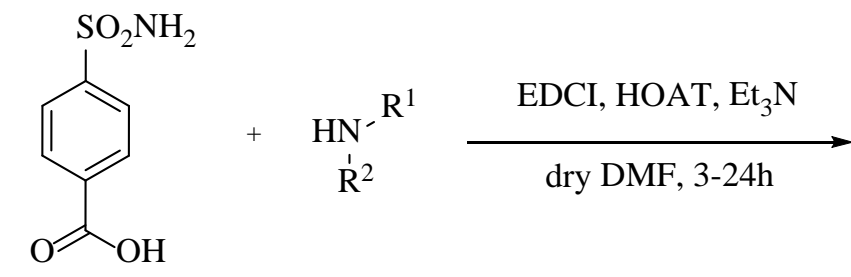

1
2 3a: $\mathrm{R}^{1}=\mathrm{H}, \mathrm{R}^{2}=\mathrm{Et}$

3b: $\mathrm{R}^{1}=\mathrm{H}, \mathrm{R}^{2}=n_{-\mathrm{Pr}}$

3c: $\mathrm{R}^{1}=\mathrm{H}, \mathrm{R}^{2}=$ Propargyl

3d: $\mathrm{R}^{1}=\mathrm{O}\left[\left(\mathrm{CH}_{2} \mathrm{CH}_{2}\right)\right]_{2}, \mathrm{R}^{2}=-$

3e: $\mathrm{R}^{1}=\left[\mathrm{C}_{2} \mathrm{H}_{4} \mathrm{C}_{2} \mathrm{H}_{4} \mathrm{CH}_{2}\right], \mathrm{R}^{2}=$

3f: $\mathrm{R}^{1}=\mathrm{H}, \mathrm{R}^{2}=$ methyl $D L$-valinate

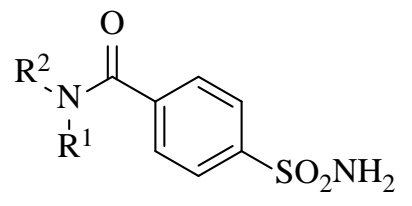

3

Scheme 1. Synthesis of compounds 3a-1.

Compound $\mathbf{1}$ was condensed with compounds $\mathbf{3 a}-\mathbf{e}$ that possess primary or secondary amines as well amino acid derivatives $\mathbf{3 f}-\mathbf{l}$ in the presence of EDCI and 1-hydroxy-7-azabenzotriazole (HOAT) to 
obtain their corresponding amides (Scheme 1). By choosing variously substituted amines and amino acids, incorporating both simple aliphatic and heterocyclic scaffolds (for the amine) and aliphatic and aromatic amino acids, the physico-chemical properties and enzyme inhibitory properties of the new compounds could be modulated. For example, the amino acid derivatives $\mathbf{3 f}, \mathbf{3} \mathbf{g}, \mathbf{3 h}, \mathbf{3} \mathbf{j}$, and 31 may form sodium salts leading to water soluble CAIs.

\subsection{Carbonic Anhydrase Inhibition}

Sulfonamides 3a-31 were tested as inhibitors of four hCAs involved in various pathologies, hCA I, II, VII, and IX, as well as three $\beta$ - and $\gamma$-CAs from pathogenic organisms: the $\beta$-CAs from the bacterium Vibrio cholerae (VchCA $\beta$ ) and the fungus Malassezia globosa (MgCA), and the $\gamma$-CA from the same pathogenic bacterium, $\mathrm{VchCA} \gamma$-enzymes recently cloned and characterized by our group as potential anti-infective targets [52-59] (Table 1).

Table 1. Inhibition data of human carbonic anhydrase (CA) isoforms hCA I, II, VII, IX, and pathogenic bacteria and fungi $\beta$ - and $\gamma$-CAs with compounds $3 \mathbf{a}-31$ in comparison with the standard sulfonamide inhibitor AAZ by a stopped flow carbon dioxide $\left(\mathrm{CO}_{2}\right)$ hydrase assay [60].

\begin{tabular}{|c|c|c|c|c|c|c|c|}
\hline \multirow[b]{2}{*}{ Cpd } & \multicolumn{7}{|c|}{$K_{I}(n M)^{a}$} \\
\hline & hCA I & hCA II & hCA VII & hCA IX & $\mathrm{VchCA} \beta$ & MgCA & VchCA $\gamma$ \\
\hline $3 a$ & 334 & 5.3 & 26.7 & 15.9 & 7082 & 7669 & 929 \\
\hline $3 b$ & 8.2 & 3.5 & 0.4 & 26.0 & 7680 & 3921 & 636 \\
\hline $3 c$ & 67.6 & 1.9 & 0.6 & 22.9 & 741 & 5781 & 383 \\
\hline $3 d$ & 8.7 & 6.2 & 0.8 & 10.7 & 8587 & 5880 & 693 \\
\hline $3 e$ & 29.7 & 7.0 & 6.2 & 18.1 & 749 & 3985 & 453 \\
\hline $3 f$ & 57.8 & 4.5 & 3.7 & 16.0 & 8172 & 5500 & 4458 \\
\hline $3 g$ & 8.2 & 5.2 & 0.6 & 19.7 & 862 & 632 & 503 \\
\hline $3 h$ & 5.6 & 3.7 & 0.4 & 8.0 & 719 & 763 & 891 \\
\hline $3 i$ & 75.7 & 6.1 & 0.7 & 12.1 & 910 & 6946 & 744 \\
\hline $3 j$ & 85.3 & 6.1 & 3.7 & 21.5 & 412 & 87.3 & 271 \\
\hline $3 k$ & 5.3 & 4.0 & 0.4 & 9.3 & 953 & 6695 & 756 \\
\hline 31 & 5.6 & 3.3 & 0.5 & 19.2 & 663 & 517 & 409 \\
\hline AAZ & 250.0 & 12.1 & 5.7 & 25.8 & 451 & 74000 & 473 \\
\hline
\end{tabular}

${ }^{a}$ Mean from three different assay using a stopped flow technique. Errors were in the range of $\pm 5 \%$ to $10 \%$ of the reported values.

\section{Discussion}

The following structure-activity relationship (SAR) were determined from the data of Table 1, in which the standard sulfonamide inhibitor acetazolamide (AAZ) was also included for comparison.

The slow cytosolic isoform hCAI, involved in some ocular diseases (not glaucoma) [3-7], was inhibited by sulfonamides $\mathbf{3 a}-\mathbf{1}$ reported here with $\mathrm{K}_{\mathrm{I}} \mathrm{s}$ in the range of 5.3 to $334 \mathrm{nM}$. The ethyl- (3a) derivative was the weakest inhibitor, whereas $\mathbf{3} \mathbf{c}, \mathbf{3} \mathbf{f}, \mathbf{3} \mathbf{i}$, and $\mathbf{3} \mathbf{j}$ showed medium potency inhibitory action, with a $\mathrm{K}_{\mathrm{I}} \mathrm{S}$ in the range of 57.8 to 85.3. These compounds incorporate propargyl, valyl, aspartyl, and alanyl moieties. The remaining derivatives, $\mathbf{3 b}, \mathbf{3 d}, \mathbf{3 e}, \mathbf{3 g}, \mathbf{3 h}, \mathbf{3 k}$, and $\mathbf{3 l}$ showed very effective hCA I inhibitory properties, with a $\mathrm{K}_{\mathrm{I}} \mathrm{s}$ in the range of 5.3 to $29.7 \mathrm{nM}$, being CAIs an order of magnitude better compared to acetazolamide (Table 1). Small changes in the scaffold (compare $\mathbf{3 a}$ and $\mathbf{3 b}$ ) led to dramatic changes in the hCA I inhibitory effects, with the propyl derivative $3 \mathbf{b}$ being 40.7 times more effective an inhibitor compared with the ethyl derivative $\mathbf{3 a}$.

All sulfonamides $\mathbf{3 a}-\mathbf{1}$ reported here were excellent hCA II inhibitors, with a $\mathrm{K}_{\mathrm{I}} \mathrm{s}$ in the range of 1.9 to $7.0 \mathrm{nM}$, thus being more effective than AAZ (Table 1). With this highly effective inhibition and small range in the variation of the $\mathrm{K}_{\mathrm{I}} \mathrm{S}$, the $\mathrm{SAR}$ is flat and the only conclusion is that all the explored substitution patterns led to highly effective hCA II inhibitors. This is also the dominant 
cytosolic isoform, involved in glaucoma, diuresis, respiration, and electrolyte secretion in a multitude of tissues [3-12], meaning these results are highly significant.

The third cytosolic isoform investigated here, hCA VII, predominantly found in the brain and involved in epileptogenesis and neuropathic pain [16-24], was also effectively inhibited by sulfonamides 3a-1, which showed a $\mathrm{K}_{\mathrm{I}} \mathrm{s}$ in the range of 0.4 to $26.7 \mathrm{nM}$. Most of these compounds were sub-nanomolar hCA VII inhibitors (e.g., 3b-3d, 3g-3i, 3k, 31), being more effective by an order of magnitude compared with the standard AAZ, whereas few of them showed the same potency as AAZ $(\mathbf{3 e}, \mathbf{3 f}, \mathbf{3} \mathbf{j})$ and only the ethyl derivative $\mathbf{3 a}$ was a less effective inhibitor compared to $\mathbf{A A Z}$, with a $\mathrm{K}_{\mathrm{I}}$ of $26.7 \mathrm{nM}$. Overall, the SAR is extremely simple, and except for the ethyl derivative mentioned above, all the substitution patterns from derivatives $3 \mathbf{b}-\mathbf{3 l}$ indicated all compounds are highly effective hCA VII inhibitors.

The tumor-associated, hypoxia-inducible isoform hCA IX was effectively inhibited by sulfonamides $3 \mathrm{a}-\mathbf{l}$, with a $\mathrm{K}_{\mathrm{I}} \mathrm{s}$ in the range of 8.0 to $26.0 \mathrm{nMh}$. AAZ has an inhibition constant of $25.8 \mathrm{nM}$ against this isoform. The most effective inhibitors, $3 \mathbf{h}$ and $3 \mathbf{k}$, with a $\mathrm{K}_{\mathrm{I}} \mathrm{s}$ of 8.0-9.3 nM, incorporated amino acyl moieties, but all substitution patterns present in compound $\mathbf{3}$, of the amine or amino acid type, led to highly effective hCA IX inhibition.

Conversely, the $\beta$ - and $\gamma$-CAs from pathogenic organisms investigated here were poorly inhibited by these compounds, which showed activity in the micromolar range, with few exceptions (Table 1). Thus, for $\mathrm{VchCA} \beta$, the $\mathrm{K}_{\mathrm{I}} \mathrm{S}$ was in the range of 0.41 to $8.58 \mu \mathrm{M}$; for $\mathrm{MgCA}$, in the range of $87.3 \mathrm{nM}$ to $7.67 \mu \mathrm{M}$; and for VchCA $\gamma$, in the range of 0.27 to $4.45 \mu \mathrm{M}$. Notably, $3 \mathbf{j}$ compounds, which incorporate the alanyl moiety, showed a good inhibitory effect against the Malassezia enzyme, one of the causative agents of dandruff. Acetazolamide is a highly ineffective MgCA inhibitor, and most other sulfonamides investigated here, although less effective than $3 \mathbf{j}$, showed a better activity compared with the standard sulfonamide CAI. Overall, $\beta$ - and $\gamma$-CAs are less sensitive to inhibition with sulfonamides compared with $\alpha$-CAs [3-14].

\section{Materials and Methods}

\subsection{Chemistry}

Amines, 4-sulfamoyl-benzoic acid, buffers, solvents, and acetazolamide (AAZ) were commercially available, obtained as highest purity reagents from Sigma-Aldrich/Merck, Milan, Italy. Nuclear magnetic resonance $\left({ }^{1} \mathrm{H}\right.$ NMR, ${ }^{13} \mathrm{C}$ NMR) spectra were recorded using a Bruker Avance III $400 \mathrm{MHz}$ spectrometer (Bruker, Billerica, MA, USA) in dimethyl sulfoxide (DMSO- $d_{6 I}$ ). Chemical shifts are reported in parts per million (ppm) and the coupling constants $(J)$ are expressed in Hertz $(\mathrm{Hz})$. Splitting patterns were designated as follows: $s$, singlet; $d$, doublet; $t$, triplet; $m$, multiplet; brs, broad singlet; and dd, double of doubles. The assignment of exchangeable protons $(\mathrm{OH}$ and $\mathrm{NH})$ was confirmed by the addition of $\mathrm{D}_{2} \mathrm{O}$. Analytical thin-layer chromatography (TLC) was performed on Merck silica gel F-254 plates. Flash chromatography purifications were performed on Merck Silica gel 60 (230-400 mesh ASTM) as the stationary phase and $\mathrm{MeOH} / \mathrm{DCM}$ were used as eluents.

\subsubsection{General Procedure to Synthesize Compounds 3a-1}

A solution of 4-carboxybenzene sulfonamide 1 (1.0 eq) in dry dimethylformamide (DMF, 3-5 mL) was treated with primary or secondary amines or amino acids $\mathbf{2 a}-\mathbf{1}(1.2 \mathrm{eq})$, then followed by addition of $N$-(3-dimethylaminopropyl)- $N^{\prime}$-ethylcarbodiimide hydrochloride (EDCI, 1.5 eq.), 1-hydroxy-7-azabenzotriazole (HOAT, $1.5 \mathrm{eq})$, and triethylamine $\left(\mathrm{Et}_{3} \mathrm{~N}, 3 \mathrm{eq}\right)$. The reaction continued until the consumption of starting materials (TLC monitoring, 3-24 h) and quenched with water. The title compounds were either obtained from filtration of the precipitates formed followed by washing with water (3a-3e, $\mathbf{3 h}, \mathbf{3 k} \mathbf{- 1})$ or extracted from ethyl acetate (EtOAc). In the latter, the combined organic layers were washed with $\mathrm{H}_{2} \mathrm{O}(3 \times 20 \mathrm{~mL})$, dried over sodium sulfate, filtered, and concentrated in a vacuum to provide a residue that was triturated from dichloromethane $(3 \mathbf{f}-\mathbf{g}, 3 \mathbf{i}-\mathbf{j})$. 


\subsubsection{Characterization of Synthesized Compounds (3a-1)}

N-Ethyl-4-Sulfamoylbenzamide (3a): $140 \mathrm{mg}$ white solid, yield 83\%; $\delta_{\mathrm{H}}\left(400 \mathrm{MHz}, \mathrm{DMSO}-d_{6}\right) 1.17(3 \mathrm{H}$, $\mathrm{t}, J$ 7.2), $3.33(2 \mathrm{H}, \mathrm{m}), 7.51\left(2 \mathrm{H}, \mathrm{s}\right.$, exchange with $\left.\mathrm{D}_{2} \mathrm{O}, \mathrm{SO}_{2} \mathrm{NH}_{2}\right), 7.93(2 \mathrm{H}, \mathrm{d}, J 8.4), 8.02(2 \mathrm{H}, \mathrm{d}, J 8.4)$, $8.68\left(1 \mathrm{H}, \mathrm{t}, J 7.2\right.$ exchange with $\left.\mathrm{D}_{2} \mathrm{O}, \mathrm{NH}\right) ; \delta_{\mathrm{C}}\left(100 \mathrm{MHz}, \mathrm{DMSO}-d_{6}\right) 15.5,35.1,126.5,128.6,138.5,147.0$, and 165.8; $\mathrm{m} / \mathrm{z}$ (ESI positive) $229.0[\mathrm{M}+\mathrm{H}]^{+}$.

$N$-Propyl-4-Sulfamoylbenzamide (3b): $120 \mathrm{mg}$ white solid, yield 80\%; $\delta_{\mathrm{H}}\left(400 \mathrm{MHz}, \mathrm{DMSO}-d_{6}\right) 0.93$ $(3 \mathrm{H}, \mathrm{t}, J 7.2), 1.58(2 \mathrm{H}, \mathrm{m}), 3.27(2 \mathrm{H}, \mathrm{q}, J 7.2), 7.50\left(2 \mathrm{H}, \mathrm{s}\right.$, exchange with $\left.\mathrm{D}_{2} \mathrm{O}, \mathrm{SO}_{2} \mathrm{NH}_{2}\right), 7.93(2 \mathrm{H}, \mathrm{d}, J$ 8.4), $8.02\left(2 \mathrm{H}, \mathrm{d}, J\right.$ 8.4), $8.66\left(1 \mathrm{H}, \mathrm{t}, J\right.$ 7.2, exchange with $\left.\mathrm{D}_{2} \mathrm{O}, \mathrm{NH}\right) ; \delta_{\mathrm{C}}\left(100 \mathrm{MHz}, \mathrm{DMSO}-d_{6}\right)$ 12.3, 23.2, $42.0,126.5,128.7,138.5,147.0,166.0 ; \mathrm{m} / z$ (ESI positive) $243.1[\mathrm{M}+\mathrm{H}]^{+}$.

N-(Prop-2-Yn-1-Yl)-4-Sulfamoylbenzamide (3c): $120 \mathrm{mg}$ yellow solid, yield 74\%; $\delta_{\mathrm{H}}(400 \mathrm{Mhz}$, DMSO- $\left.d_{6}\right) 3.18(1 \mathrm{H}, \mathrm{T}, J 2.5), 4.12(2 \mathrm{H}, \mathrm{dd}, J 5.5,2.5), 7.52\left(2 \mathrm{H}, \mathrm{s}\right.$, exchange with $\left.\mathrm{D}_{2} \mathrm{O}, \mathrm{SO}_{2} \mathrm{NH}_{2}\right)$, $7.94\left(2 \mathrm{H}, \mathrm{d}, J\right.$ 8.8), $8.04(2 \mathrm{H}, \mathrm{d}, J 8.8), 9.16\left(1 \mathrm{H}, \mathrm{t}, J 5.5\right.$, exchange with $\left.\mathrm{D}_{2} \mathrm{O}, \mathrm{NH}\right) ; \delta_{\mathrm{c}}\left(100 \mathrm{Mhz}, \mathrm{DMSO}-d_{6}\right)$ $29.5,73.9,81.9,126.5,128.8,137.6,147.3,165.8 ; \mathrm{m} / \mathrm{z}$ (ESI Positive) $239.0[\mathrm{M}+\mathrm{H}]^{+}$. Experimental data in agreement with reported data [61].

4-(Morpholine-4-Carbonyl)Benzenesulfonamide (3d): $10 \mathrm{mg}$ pale yellow solid; $9 \%$ yield; $\delta_{\mathrm{H}}(400 \mathrm{MHz}$, DMSO-d $\left.d_{6}\right) 3.65(8 \mathrm{H}, \mathrm{m}), 7.44\left(2 \mathrm{H}, \mathrm{s}\right.$, exchange with $\left.\mathrm{D}_{2} \mathrm{O}, \mathrm{SO}_{2} \mathrm{NH}_{2}\right), 7.63(2 \mathrm{H}, \mathrm{d}, J$ J 8.0$), 7.92(2 \mathrm{H}, \mathrm{d}, J 8.0)$; $\delta_{\mathrm{C}}\left(100 \mathrm{MHz}, \mathrm{DMSO}-d_{6}\right) 66.9,66.9,126.7,128.5,139.7,145.8,168.8 ; m / z$ (ESI positive) $271.1[\mathrm{M}+\mathrm{H}]^{+}$.

4-(Piperidine-1-Carbonyl)Benzenesulfonamide (3e): $12 \mathrm{mg}$ yellow solid, yield 18\%; $\delta_{\mathrm{H}}(400 \mathrm{MHz}$, DMSO-d $\left.d_{6}\right) 1.50(2 \mathrm{H}, \mathrm{m}), 1.65(4 \mathrm{H}, \mathrm{m}), 3.25(2 \mathrm{H}, \mathrm{m}), 3.63(2 \mathrm{H}, \mathrm{m}), 7.48\left(2 \mathrm{H}\right.$, s, exchange with $\mathrm{D}_{2} \mathrm{O}$, $\mathrm{SO}_{2} \mathrm{NH}_{2}$ ), 7.59 (2H, d, J 8.0), $7.91\left(2 \mathrm{H}, \mathrm{d}, J\right.$ 8.0); $\delta_{\mathrm{C}}\left(100 \mathrm{MHz}, \mathrm{DMSO}-d_{6}\right)$ 26.1, 26.7, 48.8, 126.7, 128.0, $140.7,145.4,168.5 ; \mathrm{m} / z$ (ESI positive) $269.1[\mathrm{M}+\mathrm{H}]^{+}$.

Methyl (4-Sulfamoylbenzoyl)-DL-Valinate (3f): $12 \mathrm{mg}$ pale yellow solid, yield 10\%; $\delta_{\mathrm{H}}(400 \mathrm{MHz}$, DMSO-d $)_{6} 0.98(3 \mathrm{H}, \mathrm{d}, J$ 6.8), $1.02(3 \mathrm{H}, \mathrm{d}, J 6.8), 2.23(1 \mathrm{H}, \mathrm{m}), 3.70(3 \mathrm{H}, \mathrm{s}), 4.36(1 \mathrm{H}, \mathrm{t}, J 6.8), 7.53(2 \mathrm{H}, \mathrm{s}$, exchange with $\left.\mathrm{D}_{2} \mathrm{O}, \mathrm{SO}_{2} \mathrm{NH}_{2}\right), 7.94(2 \mathrm{H}, \mathrm{d}, J 8.4), 8.05(2 \mathrm{H}, \mathrm{d}, J 8.4), 8.83(1 \mathrm{H}, \mathrm{d}, J$ 6.8, exchange with $\left.\mathrm{D}_{2} \mathrm{O}, \mathrm{NH}\right) ; \delta_{\mathrm{C}}\left(100 \mathrm{MHz}, \mathrm{DMSO}-d_{6}\right) 19.9,20.0,30.5,52.6,59.6,126.4,129.2,137.7,147.4,167.0,172.9$; $m / z$ (ESI positive) $315.0[\mathrm{M}+\mathrm{H}]^{+}$.

Dimethyl (4-Sulfamoylbenzoyl)-D-Glutamate (3g): $14 \mathrm{mg}$ pale yellow solid, yield 16\%; $\delta_{\mathrm{H}}(400 \mathrm{Mhz}$, DMSO-d $\left.d_{6}\right) 2.07(2 \mathrm{H}, \mathrm{m}), 2.16(2 \mathrm{H}, \mathrm{m}), 3.63(3 \mathrm{H}, \mathrm{s}), 3.70(3 \mathrm{H}, \mathrm{s}), 4.53(1 \mathrm{H}, \mathrm{m}), 7.52(2 \mathrm{H}, \mathrm{s}$, exchange with $\left.\mathrm{D}_{2} \mathrm{O}, \mathrm{SO}_{2} \mathrm{NH}_{2}\right), 7.94\left(2 \mathrm{H}, \mathrm{d}, J\right.$ 8.8), $8.05\left(2 \mathrm{H}, \mathrm{d}, J\right.$ 8.8), $8.83\left(1 \mathrm{H}, \mathrm{d}, J\right.$ 7.3, exchange with $\left.\mathrm{D}_{2} \mathrm{O}, \mathrm{NH}\right) ; \delta_{\mathrm{C}}$ (100 Mhz, DMSO- $\left.d_{6}\right)$ 26.6, 30.8, 52.3, 52.9, 53.0, 126.5, 129.0, 137.4, 147.5, 166.6, 172.9, 173.5; $\mathrm{m} / z$ (ESI Positive) $359.1[\mathrm{M}+\mathrm{H}]^{+}$.

Methyl (4-Sulfamoylbenzoyl)-L-Leucinate (3h): $37 \mathrm{mg}$ white solid, yield $25 \% ; \delta_{\mathrm{H}}\left(400 \mathrm{Mhz}, \mathrm{DMSO}-d_{6}\right)$ $0.92(3 \mathrm{H}, \mathrm{d}, J$ 6.4) $0.97(3 \mathrm{H}, \mathrm{d}, J 6.4), 1.63(1 \mathrm{H}, \mathrm{m}), 1.70-1.86(2 \mathrm{H}, \mathrm{m}), 3.69(3 \mathrm{H}, \mathrm{s}), 4.56(1 \mathrm{H}, \mathrm{m}), 7.52$ $\left(2 \mathrm{H}, \mathrm{s}\right.$, exchange with $\left.\mathrm{D}_{2} \mathrm{O}, \mathrm{SO}_{2} \mathrm{NH}_{2}\right), 7.95(2 \mathrm{H}, \mathrm{d}, J$ 8.3), $8.06(2 \mathrm{H}, \mathrm{d}, J$ 8.3), $8.94(1 \mathrm{H}, \mathrm{d}, J$ 6.4, exchange with $\left.\mathrm{D}_{2} \mathrm{O}, \mathrm{NH}\right) ; \delta_{\mathrm{C}}\left(100 \mathrm{Mhz}\right.$, DMSO- $\left.d_{6}\right)$ 22.1, 23.7, 25.3, 40.2, 51.9, 52.8, 126.5, 129.0, 137.5, 147.4, 166.5, 173.8; $m / z$ (ESI Positive) $329.01[\mathrm{M}+\mathrm{H}]^{+}$.

Dimethyl (4-Sulfamoylbenzoyl)-D-Aspartate (3i): $35 \mathrm{mg}$ yellow solid, yield 50\%; $\delta_{\mathrm{H}}(400 \mathrm{Mhz}$, DMSO- $\left.d_{6}\right)$ 2.86-3.04 $(2 \mathrm{H}, \mathrm{m}), 3.67(3 \mathrm{H}, \mathrm{s}), 3.70(3 \mathrm{H}, \mathrm{s}), 4.89(1 \mathrm{H}, \mathrm{m}), 7.52(2 \mathrm{H}, \mathrm{s}$, exchange with $\left.\mathrm{D}_{2} \mathrm{O}, \mathrm{SO}_{2} \mathrm{NH}_{2}\right), 7.96\left(2 \mathrm{H}, \mathrm{d}, J\right.$ 8.7), $8.03\left(2 \mathrm{H}, \mathrm{d}, J\right.$ 8.7), $9.13\left(1 \mathrm{H}, \mathrm{d}, J\right.$ 7.6, exchange with $\left.\mathrm{D}_{2} \mathrm{O}, \mathrm{NH}\right) ; \delta_{\mathrm{C}}$ (100 Mhz, DMSO- $\left.d_{6}\right) 36.2,50.2,52.6,53.2,126.6,129.0,137.2,147.6,166.1,171.3,171.9 ; \mathrm{m} / z$ (ESI Positive) $345.0[\mathrm{M}+\mathrm{H}]^{+}$.

Methyl (4-Sulfamoylbenzoyl)-DL-Alaninate (3j): $14 \mathrm{mg}$ white solid, yield $13 \%$; $\delta_{\mathrm{H}}\left(400 \mathrm{Mhz}, \mathrm{DMSO}-d_{6}\right)$ $1.46(3 \mathrm{H}, \mathrm{d}, J \mathrm{7} .3), 3,69(3 \mathrm{H}, \mathrm{s}), 4.54(1 \mathrm{H}, \mathrm{m}), 7.51\left(2 \mathrm{H}, \mathrm{s}\right.$, exchange with $\left.\mathrm{D}_{2} \mathrm{O}, \mathrm{SO}_{2} \mathrm{NH}_{2}\right), 7.96(2 \mathrm{H}, \mathrm{d}$, J 8.4), $8.06\left(2 \mathrm{H}, \mathrm{d}, J\right.$ 8.4), $9.01\left(1 \mathrm{H}, \mathrm{d}, J\right.$ 7.3, exchange with $\left.\mathrm{D}_{2} \mathrm{O}, \mathrm{NH}\right)$; $\delta_{\mathrm{C}}\left(100 \mathrm{Mhz}, \mathrm{DMSO}-d_{6}\right)$ 17.6, 49.3, $52.8,126.5,129.0,137.4,147.4,166.2,173.8 ; \mathrm{m} / \mathrm{z}$ (ESI Positive) $287.0[\mathrm{M}+\mathrm{H}]^{+}$. 
Ethyl 4-(4-Sulfamoylbenzamido)Butanoate (3k): $80 \mathrm{mg}$ white solid, yield $58 \% ; \delta_{\mathrm{H}}$ (400 Mhz, DMSO- $d_{6}$ ) $1.20(3 \mathrm{H}, \mathrm{t}, J$ 7 7.2), $1.83(2 \mathrm{H}$, pent, J 6.8), $2.39(2 \mathrm{H}, \mathrm{t}, J 6.8), 3.31(2 \mathrm{H}, \mathrm{m}), 4.09(2 \mathrm{H}, \mathrm{q}, J$ J 7.2), $7.47(2 \mathrm{H}, \mathrm{s}$, exchange with $\left.\mathrm{D}_{2} \mathrm{O}, \mathrm{SO}_{2} \mathrm{NH}_{2}\right), 7.91(2 \mathrm{H}, \mathrm{d}, J$ J 8.0), $8.01(2 \mathrm{H}, \mathrm{d}, J$ 8.0), $8.66(1 \mathrm{H}, \mathrm{t}, J 6.8$, exchange with $\left.\mathrm{D}_{2} \mathrm{O}, \mathrm{NH}\right) ; \delta_{\mathrm{C}}\left(100 \mathrm{Mhz}\right.$, DMSO- $\left.d_{6}\right)$ 15.0, 25.3, 31.9, 39.6, 60.6, 126.5, 128.7, 138.3, 147.1, 166.1, 173.5; $\mathrm{m} / \mathrm{z}$ (ESI Positive) $315.0[\mathrm{M}+\mathrm{H}]^{+}$.

Methyl (4-Sulfamoylbenzoyl)-L-Phenylalaninate (31): $130 \mathrm{mg}$ white solid, yield $72 \% ; \delta_{\mathrm{H}}(400 \mathrm{Mhz}$, DMSO-d $\left.d_{6}\right) 3.10-3.25(2 \mathrm{H}, \mathrm{m}), 3.69(3 \mathrm{H}, \mathrm{s}), 4.70-4.76(1 \mathrm{H}, \mathrm{m}), 7.24(1 \mathrm{H}, \mathrm{m}), 7.32(4 \mathrm{H}, \mathrm{m}), 7.52(2 \mathrm{H}, \mathrm{s}$, exchange with $\left.\mathrm{D}_{2} \mathrm{O}, \mathrm{SO}_{2} \mathrm{NH}_{2}\right), 7.93(2 \mathrm{H}, \mathrm{d}, J$ 8.4), $7.98(2 \mathrm{H}, \mathrm{d}, J$ 8.4), $9.08(1 \mathrm{H}, \mathrm{d}, J 7.9$, exchange with $\left.\mathrm{D}_{2} \mathrm{O}, \mathrm{NH}\right) ; \delta_{\mathrm{C}}\left(100 \mathrm{Mhz}, \mathrm{DMSO}-d_{6}\right) 37.1,52.9,55.2,126.5,127.4,128.9,129.2,130.0,137.4,138.4,147.4$, 166.3, 172.8; $\mathrm{m} / \mathrm{z}$ (ESI Positive) $363.0[\mathrm{M}+\mathrm{H}]^{+}$.

\subsection{CA Enzyme Inhibition Assay}

An Sx.18Mv-R Applied Photophysics (Oxford, U.K.) stopped-flow instrument was used to assay he catalytic activity of various $\mathrm{CA}$ isozymes for $\mathrm{CO}_{2}$ hydration reaction [60]. Phenol red, at a concentration of $0.2 \mathrm{mM}$, was used as an indicator, working at the absorbance maximum of $557 \mathrm{~nm}$, with $10 \mathrm{mM}$ Hepes ( $\mathrm{pH} 7.5$, for $\alpha$-CAs) or TRIS ( $\mathrm{pH} 8.3$, for $\beta$ - and $\gamma$-CAs) as buffers, $0.1 \mathrm{M}$ sodium sulfate $\left(\mathrm{Na}_{2} \mathrm{SO}_{4}\right)$ (for maintaining constant ionic strength), following the CA-catalyzed $\mathrm{CO}_{2}$ hydration reaction for a period of $10 \mathrm{~s}$ at $25{ }^{\circ} \mathrm{C}$. The $\mathrm{CO}_{2}$ concentrations ranged from 1.7 to $17 \mathrm{mM}$ for the determination of the kinetic parameters and inhibition constants. For each inhibitor, at least six traces of the initial $5-10 \%$ of the reaction were used for determining the initial velocity. The uncatalyzed rates were determined in the same manner and subtracted from the total observed rates. Stock solutions of inhibitors $(10 \mathrm{mM})$ were prepared in distilled-deionized water. Dilutions up to $1 \mathrm{nM}$ were performed thereafter with the assay buffer. Enzyme and inhibitor solutions were pre-incubated together for $15 \mathrm{~min}$ (standard assay at room temperature) prior to assay, to allow for the formation of the enzyme-inhibitor complex. The inhibition constants were obtained by non-linear least-squares methods using PRISM 3 and the Cheng-Prusoff equation, as reported earlier [62-75]. All CAs were recombinant proteins produced as reported earlier by our groups [52-76].

\section{Conclusions}

We report a series of benzamides incorporating 4-sulfamoyl moieties, which were obtained by reacting 4-sulfamoyl benzoic acid with primary and secondary amines and amino acids. These sulfonamides were investigated as inhibitors of several enzymes, including the human (h) isoforms hCA II, VII, and IX, involved in severe pathologies, such as glaucoma, epilepsy, neuropathic pain and cancer; and $\beta$ - and $\gamma$-class CAs from pathogenic bacteria and fungi. hCA II, VII, and IX were inhibited in the low nanomolar or subnanomolar ranges by all investigated sulfonamides, whereas hCA I was slightly less sensitive to inhibition ( $\mathrm{K}_{\mathrm{I}} \mathrm{s}$ of 5.3-334 nM). The Vibrio cholerae and Malassezia globosa CAs were generally inhibited in the micromolar range by the sulfonamides reported in the paper. The benzamide-4-sulfonamides constitute a promising class of highly effective CA inhibitors. Further investigations will focus on extending the series of sulfanilamide possessing aliphatic tails with carbamide linkers, such as cyclic and aliphatic and aromatic, to investigate and obtain isoform selective inhibitors for their profiling and possible in vivo applications.

Author Contributions: M.A. synthesized and characterized the CAIs, A.A. performed the stopped-flow analysis. M.B. supervised to study and edited the manuscript. C.T.S. wrote and edited the manuscript. All authors read and approved the final paper

Funding: This research received no external funding

Conflicts of Interest: The authors declare no competing financial interest. 


\section{References}

1. Mincione, F.; Starnotti, M.; Menabuoni, L.; Scozzafava, A.; Casini, A.; Supuran, C.T. Carbonic anhydrase inhibitors: 4-sulfamoyl-benzenecarboxamides and 4-chloro-3-sulfamoyl-benzenecarboxamides with strong topical antiglaucoma properties. Bioorg. Med. Chem. Lett. 2001, 11, 1787-1791. [CrossRef]

2. Casini, A.; Scozzafava, A.; Mincione, F.; Menabuoni, L.; Starnotti, M.; Supuran, C.T. Carbonic anhydrase inhibitors: Topically acting antiglaucoma sulfonamides incorporating esters and amides of 3- and 4-carboxybenzolamide. Bioorg. Med. Chem. Lett. 2003, 13, 2867-2873. [CrossRef]

3. Supuran, C.T. Carbonic anhydrases: From biomedical applications of the inhibitors and activators to biotechnological use for $\mathrm{CO}_{2}$ capture. J. Enzyme Inhib. Med. Chem. 2013, 28, 229-230. [CrossRef] [PubMed]

4. Supuran, C.T. How many carbonic anhydrase inhibition mechanisms exist? J. Enzyme Inhib. Med. Chem. 2016, 31, 345-360. [CrossRef] [PubMed]

5. Alterio, V.; Di Fiore, A.; D'Ambrosio, K.; Supuran, C.T.; De Simone, G. Multiple binding modes of inhibitors to carbonic anhydrases: How to design specific drugs targeting 15 different isoforms? Chem. Rev. 2012, 112, 4421-4468. [CrossRef] [PubMed]

6. Abbate, F.; Winum, J.Y.; Potter, B.V.; Casini, A.; Montero, J.L.; Scozzafava, A.; Supuran, C.T. Carbonic anhydrase inhibitors: X-ray crystallographic structure of the adduct of human isozyme II with EMATE, a dual inhibitor of carbonic anhydrases and steroid sulfatase. Bioorg. Med. Chem. Lett. 2004, 14, 231-234. [CrossRef] [PubMed]

7. Capasso, C.; Supuran, C.T. An overview of the alpha-, beta-and gamma-carbonic anhydrases from Bacteria: Can bacterial carbonic anhydrases shed new light on evolution of bacteria? J. Enzyme Inhib. Med. Chem. 2015, 30, 325-332. [CrossRef] [PubMed]

8. Supuran, C.T. Advances in structure-based drug discovery of carbonic anhydrase inhibitors. Expert Opin. Drug Discov. 2017, 12, 61-88. [CrossRef] [PubMed]

9. Supuran, C.T. Structure and function of carbonic anhydrases. Biochem. J. 2016, 473, 2023-2032. [CrossRef] [PubMed]

10. Supuran, C.T. Carbonic anhydrases: Novel therapeutic applications for inhibitors and activators. Nat. Rev. Drug Discov. 2008, 7, 168-181. [CrossRef] [PubMed]

11. Neri, D.; Supuran, C.T. Interfering with $\mathrm{pH}$ regulation in tumours as a therapeutic strategy. Nat. Rev. Drug Discov. 2011, 10, 767-777. [CrossRef] [PubMed]

12. Supuran, C.T.; Vullo, D.; Manole, G.; Casini, A.; Scozzafava, A. Designing of novel carbonic anhydrase inhibitors and activators. Curr. Med. Chem. Cardiovasc. Hematol. Agents 2004, 2, 49-68. [CrossRef] [PubMed]

13. Carta, F.; Supuran, C.T. Diuretics with carbonic anhydrase inhibitory action: A patent and literature review (2005-2013). Expert Opin. Ther. Pat. 2013, 23, 681-691. [CrossRef] [PubMed]

14. Temperini, C.; Cecchi, A.; Scozzafava, A.; Supuran, C.T. Carbonic anhydrase inhibitors. Sulfonamide diuretics revisited-Old leads for new applications? Org. Biomol. Chem. 2008, 6, 2499-2506. [CrossRef] [PubMed]

15. Masini, E.; Carta, F.; Scozzafava, A.; Supuran, C.T. Antiglaucoma carbonic anhydrase inhibitors: A patent review. Expert Opin. Ther. Pat. 2013, 23, 705-716. [CrossRef] [PubMed]

16. Scozzafava, A.; Supuran, C.T.; Carta, F. Antiobesity carbonic anhydrase inhibitors: A literature and patent review. Expert Opin. Ther. Pat. 2013, 23, 725-735. [CrossRef] [PubMed]

17. Supuran, C.T. Carbonic anhydrases and metabolism. Metabolites 2018, 8, E25. [CrossRef] [PubMed]

18. Monti, S.M.; Supuran, C.T.; De Simone, G. Anticancer carbonic anhydrase inhibitors: A patent review (2008-2013). Expert Opin. Ther. Pat. 2013, 23, 737-749. [CrossRef] [PubMed]

19. Supuran, C.T. Carbonic Anhydrase Inhibition and the Management of Hypoxic Tumors. Metabolites 2017, 7, E48. [CrossRef] [PubMed]

20. Ward, C.; Langdon, S.P.; Mullen, P.; Harris, A.L.; Harrison, D.J.; Supuran, C.T.; Kunkler, I.H. New strategies for targeting the hypoxic tumour microenvironment in breast cancer. Cancer Treat. Rev. 2013, 39, 171-179. [CrossRef] [PubMed]

21. Garaj, V.; Puccetti, L.; Fasolis, G.; Winum, J.Y.; Montero, J.L.; Scozzafava, A.; Vullo, D.; Innocenti, A.; Supuran, C.T. Carbonic anhydrase inhibitors: Novel sulfonamides incorporating 1,3,5-triazine moieties as inhibitors of the cytosolic and tumour-associated carbonic anhydrase isozymes I, II and IX. Bioorg. Med. Chem. Lett. 2005, 15, 3102-3108. [CrossRef] [PubMed] 
22. Casey, J.R.; Morgan, P.E.; Vullo, D.; Scozzafava, A.; Mastrolorenzo, A.; Supuran, C.T. Carbonic anhydrase inhibitors. Design of selective, membrane-impermeant inhibitors targeting the human tumor-associated isozyme IX. J. Med. Chem. 2004, 47, 2337-2347. [CrossRef] [PubMed]

23. Supuran, C.T. Carbonic anhydrase inhibition and the management of neuropathic pain. Expert Rev. Neurother. 2016, 16, 961-968. [CrossRef] [PubMed]

24. Di Cesare Mannelli, L.; Micheli, L.; Carta, F.; Cozzi, A.; Ghelardini, C.; Supuran, C.T. Carbonic anhydrase inhibition for the management of cerebral ischemia: In vivo evaluation of sulfonamide and coumarin inhibitors. J. Enzyme Inhib. Med. Chem. 2016, 31, 894-899. [CrossRef] [PubMed]

25. Margheri, F.; Ceruso, M.; Carta, F.; Laurenzana, A.; Maggi, L.; Lazzeri, S.; Simonini, G.; Annunziato, F.; Del Rosso, M.; Supuran, C.T.; et al. Overexpression of the transmembrane carbonic anhydrase isoforms IX and XII in the inflamed synovium. J. Enzyme Inhib. Med. Chem. 2016, 31, 60-63. [CrossRef] [PubMed]

26. Bua, S.; Di Cesare Mannelli, L.; Vullo, D.; Ghelardini, C.; Bartolucci, G.; Scozzafava, A.; Supuran, C.T.; Carta, F. Design and Synthesis of Novel Nonsteroidal Anti-Inflammatory Drugs and Carbonic Anhydrase Inhibitors Hybrids (NSAIDs-CAIs) for the Treatment of Rheumatoid Arthritis. J. Med. Chem. 2017, 60, 1159-1170. [CrossRef] [PubMed]

27. Maresca, A.; Temperini, C.; Vu, H.; Pham, N.B.; Poulsen, S.A.; Scozzafava, A.; Quinn, R.J.; Supuran, C.T. Non-zinc mediated inhibition of carbonic anhydrases: Coumarins are a new class of suicide inhibitors. J. Am. Chem. Soc. 2009, 131, 3057-3062. [CrossRef] [PubMed]

28. Maresca, A.; Temperini, C.; Pochet, L.; Masereel, B.; Scozzafava, A.; Supuran, C.T. Deciphering the mechanism of carbonic anhydrase inhibition with coumarins and thiocoumarins. J. Med. Chem. 2010, 53, 335-344. [CrossRef] [PubMed]

29. Carta, F.; Maresca, A.; Scozzafava, A.; Supuran, C.T. Novel coumarins and 2-thioxo-coumarins as inhibitors of the tumor-associated carbonic anhydrases IX and XII. Bioorg. Med. Chem. 2012, 20, 2266-2273. [CrossRef] [PubMed]

30. Supuran, C.T. Carbonic anhydrase activators. Future Med. Chem. 2018, 10, 561-573. [CrossRef] [PubMed]

31. Alterio, V.; Cadoni, R.; Esposito, D.; Vullo, D.; Fiore, A.D.; Monti, S.M.; Caporale, A.; Ruvo, M.; Sechi, M.; Dumy, P.; et al. Benzoxaborole as a new chemotype for carbonic anhydrase inhibition. Chem. Commun. 2016, 52, 11983-11986. [CrossRef] [PubMed]

32. Nocentini, A.; Cadoni, R.; Del Prete, S.; Capasso, C.; Dumy, P.; Gratteri, P.; Supuran, C.T.; Winum, J.Y. Benzoxaboroles as Efficient Inhibitors of the $\beta$-Carbonic Anhydrases from Pathogenic Fungi: Activity and Modeling Study. ACS Med. Chem. Lett. 2017, 8, 1194-1198. [CrossRef] [PubMed]

33. Tars, K.; Vullo, D.; Kazaks, K.; Leitans, J.; Lends, A.; Grandane, A.; Zalubovskis, R.; Scozzafava, A.; Supuran, C.T. Sulfocoumarins (1,2-benzoxathiine-2,2-dioxides): A class of potent and isoform-selective inhibitors of tumor-associated carbonic anhydrases. J. Med. Chem. 2013, 56, 293-300. [CrossRef] [PubMed]

34. Métayer, B.; Mingot, A.; Vullo, D.; Supuran, C.T.; Thibaudeau, S. New superacid synthesized (fluorinated) tertiary benzenesulfonamides acting as selective hCA IX inhibitors: Toward a new mode of carbonic anhydrase inhibition by sulfonamides. Chem. Commun. 2013, 49, 6015-6017. [CrossRef] [PubMed]

35. Métayer, B.; Mingot, A.; Vullo, D.; Supuran, C.T.; Thibaudeau, S. Superacid synthesized tertiary benzenesulfonamides and benzofuzed sultams act as selective hCA IX inhibitors: Toward understanding a new mode of inhibition by tertiary sulfonamides. Org. Biomol. Chem. 2013, 11, 7540-7549. [CrossRef] [PubMed]

36. Supuran, C.T. Carbon-versus sulphur-based zinc binding groups for carbonic anhydrase inhibitors? J. Enzyme Inhib. Med. Chem. 2018, 33, 485-495. [CrossRef] [PubMed]

37. Di Fiore, A.; Maresca, A.; Supuran, C.T.; De Simone, G. Hydroxamate represents a versatile zinc binding group for the development of new carbonic anhydrase inhibitors. Chem. Commun. 2012, 48, 8838-8840. [CrossRef] [PubMed]

38. Marques, S.M.; Nuti, E.; Rossello, A.; Supuran, C.T.; Tuccinardi, T.; Martinelli, A.; Santos, M.A. Dual inhibitors of matrix metalloproteinases and carbonic anhydrases: Iminodiacetyl-based hydroxamate-benzenesulfonamide conjugates. J. Med. Chem. 2008, 51, 7968-7979. [CrossRef] [PubMed]

39. Bozdag, M.; Carta, F.; Angeli, A.; Osman, S.M.; Alasmary, F.A.S.; AlOthman, Z.; Supuran, C.T. Synthesis of $N^{\prime}$-phenyl- $N$-hydroxyureas and investigation of their inhibitory activities on human carbonic anhydrases. Bioorg. Chem. 2018, 78, 1-6. [CrossRef] [PubMed] 
40. Capasso, C.; Supuran, C.T. Bacterial, fungal and protozoan carbonic anhydrases as drug targets. Expert Opin. Ther. Targets 2015, 19, 1689-1704. [CrossRef] [PubMed]

41. Vermelho, A.B.; Da Silva Cardoso, V.; Ricci Junior, E.; Dos Santos, E.P.; Supuran, C.T. Nanoemulsions of sulfonamide carbonic anhydrase inhibitors strongly inhibit the growth of Trypanosoma cruzi. J. Enzyme Inhib. Med. Chem. 2018, 33, 139-146. [CrossRef] [PubMed]

42. de Menezes Dda, R.; Calvet, C.M.; Rodrigues, G.C.; de Souza Pereira, M.C.; Almeida, I.R.; de Aguiar, A.P.; Supuran, C.T.; Vermelho, A.B. Hydroxamic acid derivatives: A promising scaffold for rational compound optimization in Chagas disease. J. Enzyme Inhib. Med. Chem. 2016, 31, 964-973. [CrossRef] [PubMed]

43. Nocentini, A.; Cadoni, R.; Dumy, P.; Supuran, C.T.; Winum, J.Y. Carbonic anhydrases from Trypanosoma cruzi and Leishmania donovani chagasi are inhibited by benzoxaboroles. J. Enzyme Inhib. Med. Chem. 2018, 33, 286-289. [CrossRef] [PubMed]

44. Del Prete, S.; De Luca, V.; De Simone, G.; Supuran, C.T.; Capasso, C. Cloning, expression and purification of the complete domain of the $\eta$-carbonic anhydrase from Plasmodium falciparum. J. Enzyme Inhib. Med. Chem. 2016, 31, 54-59. [CrossRef] [PubMed]

45. Supuran, C.T.; Capasso, C. The $\eta$-class carbonic anhydrases as drug targets for antimalarial agents. Expert Opin. Ther. Targets 2015, 19, 551-563. [CrossRef] [PubMed]

46. Vullo, D.; Del Prete, S.; Fisher, G.M.; Andrews, K.T.; Poulsen, S.A.; Capasso, C.; Supuran, C.T. Sulfonamide inhibition studies of the $\eta$-class carbonic anhydrase from the malaria pathogen Plasmodium Falciparum. Bioorg. Med. Chem. 2015, 23, 526-531. [CrossRef] [PubMed]

47. De Simone, G.; Di Fiore, A.; Capasso, C.; Supuran, C.T. The zinc coordination pattern in the $\eta$-carbonic anhydrase from Plasmodium falciparum is different from all other carbonic anhydrase genetic families. Bioorg. Med. Chem. Lett. 2015, 25, 1385-1389. [CrossRef] [PubMed]

48. Modak, J.K.; Liu, Y.C.; Supuran, C.T.; Roujeinikova, A. Structure-Activity Relationship for Sulfonamide Inhibition of Helicobacter pylori $\alpha$-Carbonic Anhydrase. J. Med. Chem. 2016, 59, 11098-11109. [CrossRef] [PubMed]

49. Buzás, G.M.; Supuran, C.T. The history and rationale of using carbonic anhydrase inhibitors in the treatment of peptic ulcers. In memoriam Ioan Puşcaş (1932-2015). J. Enzyme Inhib. Med. Chem. 2016, 31, 527-533. [CrossRef] [PubMed]

50. Supuran, C.T. Bacterial carbonic anhydrases as drug targets: Toward novel antibiotics? Front. Pharmacol. 2011, 2, 34. [CrossRef] [PubMed]

51. Nishimori, I.; Onishi, S.; Takeuchi, H.; Supuran, C.T. The alpha and beta classes carbonic anhydrases from Helicobacter pylori as novel drug targets. Curr. Pharm. Des. 2008, 14, 622-630. [CrossRef] [PubMed]

52. De Vita, D.; Angeli, A.; Pandolfi, F.; Bortolami, M.; Costi, R.; Di Santo, R.; Suffredini, E.; Ceruso, M.; Del Prete, S.; Capasso, C.; et al. Inhibition of the $\alpha$-carbonic anhydrase from Vibrio cholerae with amides and sulfonamides incorporating imidazole moieties. J. Enzyme Inhib. Med. Chem. 2017, 32, 798-804. [CrossRef] [PubMed]

53. Del Prete, S.; Vullo, D.; De Luca, V.; Carginale, V.; Ferraroni, M.; Osman, S.M.; AlOthman, Z.; Supuran, C.T.; Capasso, C. Sulfonamide inhibition studies of the $\beta$-carbonic anhydrase from the pathogenic bacterium Vibrio cholerae. Bioorg. Med. Chem. 2016, 24, 1115-1120. [CrossRef] [PubMed]

54. Del Prete, S.; Isik, S.; Vullo, D.; De Luca, V.; Carginale, V.; Scozzafava, A.; Supuran, C.T.; Capasso, C. DNA cloning, characterization, and inhibition studies of an $\alpha$-carbonic anhydrase from the pathogenic bacterium Vibrio cholerae. J. Med. Chem. 2012, 55, 10742-10748. [CrossRef] [PubMed]

55. Del Prete, S.; Vullo, D.; De Luca, V.; Carginale, V.; di Fonzo, P.; Osman, S.M.; AlOthman, Z.; Supuran, C.T.; Capasso, C. Anion inhibition profiles of $\alpha-, \beta$ - and $\gamma$-carbonic anhydrases from the pathogenic bacterium Vibrio cholerae. Bioorg. Med. Chem. 2016, 24, 3413-3417. [CrossRef] [PubMed]

56. Angeli, A.; Del Prete, S.; Osman, S.M.; Alasmary, F.A.S.; AlOthman, Z.; Donald, W.A.; Capasso, C.; Supuran, C.T. Activation studies of the $\alpha$ - and $\beta$-carbonic anhydrases from the pathogenic bacterium Vibrio cholerae with amines and amino acids. J. Enzyme Inhib. Med. Chem. 2018, 33, 227-233. [CrossRef] [PubMed]

57. Del Prete, S.; De Luca, V.; Vullo, D.; Osman, S.M.; AlOthman, Z.; Carginale, V.; Supuran, C.T.; Capasso, C. A new procedure for the cloning, expression and purification of the $\beta$-carbonic anhydrase from the pathogenic yeast Malassezia globosa, an anti-dandruff drug target. J. Enzyme Inhib. Med. Chem. 2016, 31, 1156-1161. [CrossRef] [PubMed] 
58. Nocentini, A.; Vullo, D.; Del Prete, S.; Osman, S.M.; Alasmary, F.A.S.; AlOthman, Z.; Capasso, C.; Carta, F.; Gratteri, P.; Supuran, C.T. Inhibition of the $\beta$-carbonic anhydrase from the dandruff-producing fungus Malassezia globosa with monothiocarbamates. J. Enzyme Inhib. Med. Chem. 2017, 32, 1064-1070. [CrossRef] [PubMed]

59. Angiolella, L.; Carradori, S.; Maccallini, C.; Giusiano, G.; Supuran, C.T. Targeting Malassezia species for Novel Synthetic and Natural Antidandruff Agents. Curr. Med. Chem. 2017, 24, 2392-2412. [CrossRef] [PubMed]

60. Khalifah, R.G. The carbon dioxide hydration activity of carbonic anhydrase. I. Stop-flow kinetic studies on the native human isoenzymes B and C. J. Biol. Chem. 1971, 246, 2561-2573. [PubMed]

61. Wilkinson, B.L.; Bornaghi, L.F.; Houston, T.A.; Innocenti, A.; Supuran, C.T.; Poulsen, S.A. A novel class of carbonic anhydrase inhibitors: Glycoconjugate benzene sulfonamides prepared by “click-tailing". J. Med. Chem. 2006, 49, 6539-6548. [CrossRef] [PubMed]

62. Diaz, J.R.; Fernández Baldo, M.; Echeverría, G.; Baldoni, H.; Vullo, D.; Soria, D.B.; Supuran, C.T.; Camí, G.E. A substituted sulfonamide and its $\mathrm{Co}$ (II), $\mathrm{Cu}$ (II), and $\mathrm{Zn}$ (II) complexes as potential antifungal agents. J. Enzyme Inhib. Med. Chem. 2016, 31, 51-62. [CrossRef] [PubMed]

63. Menchise, V.; De Simone, G.; Alterio, V.; Di Fiore, A.; Pedone, C.; Scozzafava, A.; Supuran, C.T. Carbonic anhydrase inhibitors: Stacking with Phe131 determines active site binding region of inhibitors as exemplified by the X-ray crystal structure of a membrane-impermeant antitumor sulfonamide complexed with isozyme II. J. Med. Chem. 2005, 48, 5721-5727. [CrossRef] [PubMed]

64. Supuran, C.T.; Mincione, F.; Scozzafava, A.; Briganti, F.; Mincione, G.; Ilies, M.A. Carbonic anhydrase inhibitors-Part 52. Metal complexes of heterocyclic sulfonamides: A new class of strong topical intraocular pressure-lowering agents in rabbits. Eur. J. Med. Chem. 1998, 33, 247-254. [CrossRef]

65. Şentürk, M.; Gülçin, İ.; Beydemir, Ş.; Küfrevioğlu, O.İ.; Supuran, C.T. In vitro inhibition of human carbonic anhydrase I and II isozymes with natural phenolic compounds. Chem. Biol. Drug Des. 2011, 77, 494-499. [CrossRef] [PubMed]

66. Fabrizi, F.; Mincione, F.; Somma, T.; Scozzafava, G.; Galassi, F.; Masini, E.; Impagnatiello, F.; Supuran, C.T. A new approach to antiglaucoma drugs: Carbonic anhydrase inhibitors with or without NO donating moieties. Mechanism of action and preliminary pharmacology. J. Enzyme Inhib. Med. Chem. 2012, 27, 138-147. [CrossRef] [PubMed]

67. Krall, N.; Pretto, F.; Decurtins, W.; Bernardes, G.J.; Supuran, C.T.; Neri, D. A Small-Molecule Drug Conjugate for the Treatment of Carbonic Anhydrase IX Expressing Tumors. Angew. Chem. Int. Ed. Engl. 2014, 53, 4231-4235. [CrossRef] [PubMed]

68. Rehman, S.U.; Chohan, Z.H.; Gulnaz, F.; Supuran, C.T. In-vitro antibacterial, antifungal and cytotoxic activities of some coumarins and their metal complexes. J. Enzyme Inhib. Med. Chem. 2005, 20, 333-340. [CrossRef] [PubMed]

69. Clare, B.W.; Supuran, C.T. Carbonic anhydrase activators. 3: Structure-activity correlations for a series of isozyme II activators. J. Pharm. Sci. 1994, 83, 768-773. [CrossRef] [PubMed]

70. Dubois, L.; Peeters, S.; Lieuwes, N.G.; Geusens, N.; Thiry, A.; Wigfield, S.; Carta, F.; McIntyre, A.; Scozzafava, A.; Dogné, J.M.; et al. Specific inhibition of carbonic anhydrase IX activity enhances the in vivo therapeutic effect of tumor irradiation. Radiother. Oncol. 2011, 99, 424-431. [CrossRef] [PubMed]

71. Chohan, Z.H.; Munawar, A.; Supuran, C.T. Transition metal ion complexes of Schiff-bases. Synthesis, characterization and antibacterial properties. Met. Based Drugs 2001, 8, 137-143. [CrossRef] [PubMed]

72. Zimmerman, S.A.; Ferry, J.G.; Supuran, C.T. Inhibition of the archaeal $\beta$-class (Cab) and $\gamma$-class (Cam) carbonic anhydrases. Curr. Top. Med. Chem. 2007, 7, 901-908. [CrossRef] [PubMed]

73. Supuran, C.T.; Nicolae, A.; Popescu, A. Carbonic anhydrase inhibitors. Part 35. Synthesis of Schiff bases derived from sulfanilamide and aromatic aldehydes: The first inhibitors with equally high affinity towards cytosolic and membrane-bound isozymes. Eur. J. Med. Chem. 1996, 31, 431-438. [CrossRef]

74. Pacchiano, F.; Aggarwal, M.; Avvaru, B.S.; Robbins, A.H.; Scozzafava, A.; McKenna, R.; Supuran, C.T. Selective hydrophobic pocket binding observed within the carbonic anhydrase II active site accommodate different 4-substituted-ureido-benzenesulfonamides and correlate to inhibitor potency. Chem. Commun. 2010, 46, 8371-8373. [CrossRef] [PubMed] 
75. Ozensoy Guler, O.; Capasso, C.; Supuran, C.T. A magnificent enzyme superfamily: Carbonic anhydrases, their purification and characterization. J. Enzyme Inhib. Med. Chem. 2016, 31, 689-694. [CrossRef] [PubMed]

76. De Simone, G.; Langella, E.; Esposito, D.; Supuran, C.T.; Monti, S.M.; Winum, J.Y.; Alterio, V. Insights into the binding mode of sulphamates and sulphamides to hCA II: Crystallographic studies and binding free energy calculations. J. Enzyme Inhib. Med. Chem. 2017, 32, 1002-1011. [CrossRef] [PubMed] 